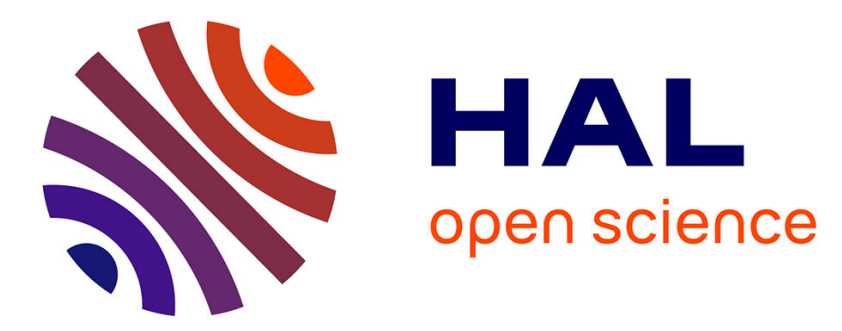

\title{
Deformation studies at Furnas and Sete Cidades Volcanoes (São Miguel Island, Azores). Velocities and further investigations
}

A. Trota, N. Houlié, Pierre Briole, J. L Gaspar, F. Sigmundsson, K.L. Feigl

\section{To cite this version:}

A. Trota, N. Houlié, Pierre Briole, J. L Gaspar, F. Sigmundsson, et al.. Deformation studies at Furnas and Sete Cidades Volcanoes (São Miguel Island, Azores). Velocities and further investigations. Geophysical Journal International, 2006, 166 (2), pp.952-956. 10.1111/j.1365-246X.2006.03039.x . hal-00272454

\section{HAL Id: hal-00272454 \\ https://hal.science/hal-00272454}

Submitted on 4 Jul 2017

HAL is a multi-disciplinary open access archive for the deposit and dissemination of scientific research documents, whether they are published or not. The documents may come from teaching and research institutions in France or abroad, or from public or private research centers.
L'archive ouverte pluridisciplinaire HAL, est destinée au dépôt et à la diffusion de documents scientifiques de niveau recherche, publiés ou non, émanant des établissements d'enseignement et de recherche français ou étrangers, des laboratoires publics ou privés. 


\title{
Deformation studies at Furnas and Sete Cidades Volcanoes (São Miguel Island, Azores). Velocities and further investigations
}

\author{
A. Trota, ${ }^{1}$ N. Houlié, ${ }^{2, *}$ P. Briole, ${ }^{3}$ J. L. Gaspar, ${ }^{1}$ F. Sigmundsson ${ }^{4}$ and K. L. Feigl ${ }^{5}$ \\ ${ }^{1}$ Centro Vulcanologia e Avaliação Riscos Geológicos (CVARG) Departemento de Geosciências, University of Azores, \\ 9501-801 Ponta Delgada, Azores, Portugal \\ ${ }^{2}$ Equipe de Sismologie, Institut de Physique du Globe de Paris, 4 Place Jussieu 75252 Paris cedex 05, France. E-mail: houlie@seismo.berkeley.edu \\ ${ }^{3}$ Equipe de Géodésie, Institut de Physique du Globe de Paris, 4 Place Jussieu 75252 Paris cedex 05, France \\ ${ }^{4}$ Nordic Volcanological Institute, University of Iceland, Grensàsvegur 50, 108 Reykjavik, Iceland \\ ${ }^{5}$ Centre National de la Recherche Scientifique, Toulouse, France
}

Accepted 2006 April 11. Received 2006 April 10; in original form 2005 January 6

\begin{abstract}
SUMMAR Y
The Azores archipelago is located near the triple junction between the Nubian (NU), North America (NA), and Eurasia (EU) plates. It is characterized by a relatively strong seismicity and active volcanism. The best estimate of the current plate velocities in the area over geologic timescales comes from the NUVEL1-NNR model (DeMets et al.) . At the geodetic timescale, plate motion models (Altamimi et al., Sella et al.) including GPS, DORIS, SLR and VLBI data currently do not yet include data from the Azores. In the framework of a research project focused on the seismotectonics and volcanotectonics of São Miguel island, we have analysed GPS data collected there in 1993, 1994, 1997, 2000 and 2002. Our analysis determines both the velocity in the REVEL (Sella et al.) reference frame of São Miguel and its internal deformation. The comparison of the 2000 and 2002 coordinates indicates that São Miguel accommodates moderate WNW-ESE extension at a rate slower than $5 \mathrm{~mm} \mathrm{yr}^{-1}$.
\end{abstract}

Key words: Azores, geodesy, geodynamic, GPS, volcanology.

\section{INTRODUCTION}

The Azores archipelago (Fig. 1) is located in the so-called Terceira Rift (Machado 1959) a complex tectonic area connecting the Mid-Atlantic Ridge (MAR) and the east-west Gloria fault where the Nubian, American and Eurasia plates meet (Searle 1980). São Miguel island lies in the eastern part of the Terceira Rift. Here we present a geodetic study of the São Miguel Island focused on the three main active stratovolcanoes: Sete Cidades, Fogo (also called Água de Pau), and Furnas. The oldest rocks of São Miguel island date from 4.01 Ma (Abdel-Monem et al. 1975). Several historical eruptions took place on land (Furnas Volcano: 1439-1443 (?), 1630; Fogo Volcano: 1563, 1564; Picos Basaltic Volcanic System 1563, $1652)$ and offshore $(1811,1907,1911,1981)$ since the settlement of the island in the 15th century (Weston 1964; Queiroz 1998).

Currently, volcanotectonic activity on this island is moderate with a low-level continuous microseismicity superimposed by important seismic swarms with tectonic and volcanic signatures (Fig. 2). This work is the result of an international scientific collaboration. In the mid-1990's, Portuguese and Icelandic volcanologists studied two of the three stratovolcanoes of São Miguel Island: Furnas and Fogo

\footnotetext{
*Now at: University of California-Berkeley Seismological Laboratory. 217 Mc Cone Hall 94720-4760 Berkeley, USA.
}

volcanoes. More recently a joint project between French and Portuguese scientists extended this work to Sete Cidades volcano. In this study, we estimate the velocity of São Miguel island in ITRF2000 reference frame (Altamimi et al. 2002) and its internal deformation.

Using the GPS observations performed between 1993 and 1999 at São Miguel, previous studies (Sigmundsson et al. 1995; Jónsson et al. 1999) found small, mostly insignificant, displacements. In 1999, the Center of Volcanology of the Azores University began to densify the GPS network on São Miguel with three objectives:

(1) to connect the old benchmarks observed in the 1990s to the newer, more easily accessible ones occupied in 2000 and 2002;

(2) to place São Miguel in the tectonic setting of a plate boundary and

(3) to investigate the internal deformation of São Miguel island, in particular the interaction between faulting and volcanic activity.

\section{DATA}

We have analysed data of five GPS campaigns organized between 1993 and 2002 (Fig. 3 and Table 1). The 1993-1999 campaigns provide mainly data from the Furnas area and a few points from Fogo volcano; they were carried out using Trimble 4000 SSE and SST pack. A few marks of the old network were destroyed. In this study, we decided to process only dual-frequency data and 


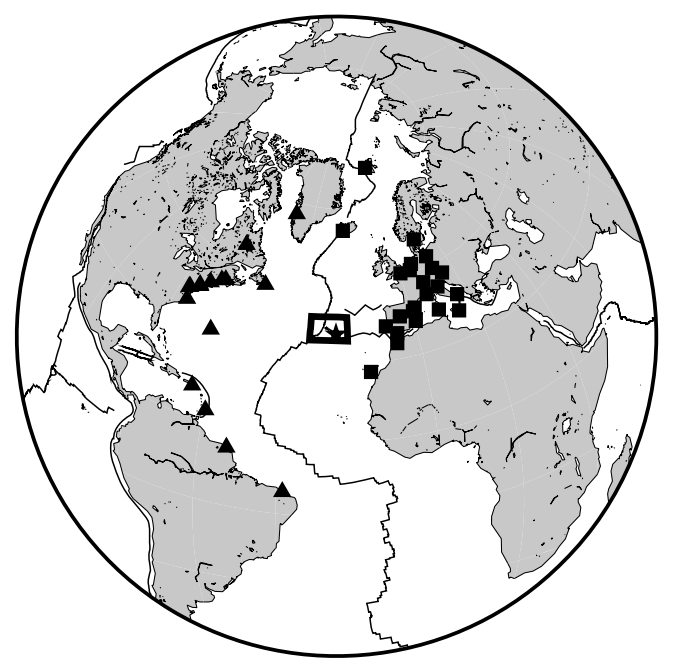

Figure 1. Location of the Azores archipelago and permanent network used to process data.

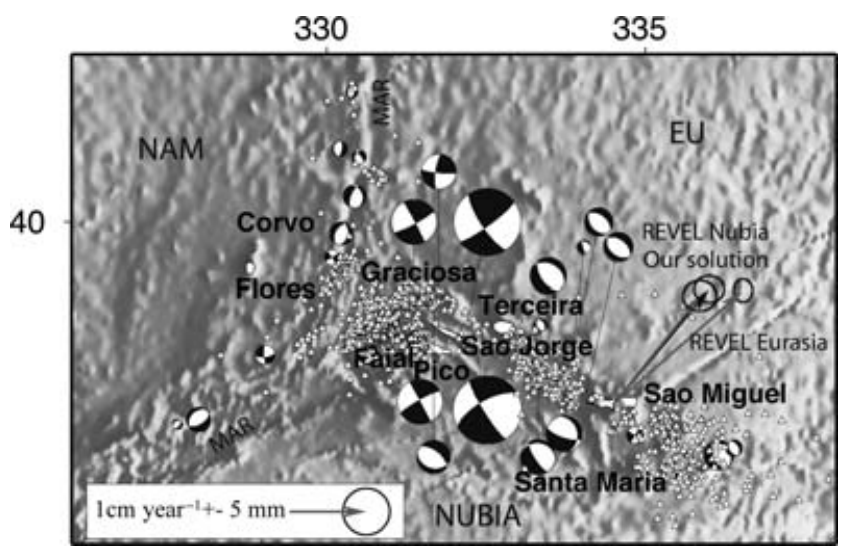

Figure 2. Shaded bathymetry and location of the nine islands of the Azores archipelago. The focal mechanisms from the Harvard and USGS catalogue (period 1976/2002, magnitude $M_{w}>5$ are plotted. The Nubia displacement is plotted following the REVEL solution (Sella et al. 2002). Our solution (black arrow) is in good agreement with the REVEL Nubia solution (grey arrow).
Table 1. List of GPS campaigns showing the mean repeatability in millimetres. Repeatability (Rep.) and the mean duration Hours are done for each campaign.

\begin{tabular}{lcccccc}
\hline Campaign & Date & Days & Sites & IGS & Rep. & Hours \\
\hline FURNAS93 & 1993.8 & 12 & 14 & 11 & 2.76 & $3-5$ \\
FURNAS94 & 1994.8 & 12 & 14 & 15 & 3.14 & $3-5$ \\
FOGO97 & 1997.4 & 19 & 14 & 11 & 2.57 & $4-6$ \\
SMIG2000 & 2000.6 & 31 & 38 & 28 & 12.00 & 2.5 \\
SMIG2002 & 2002.7 & 14 & 77 & 29 & 5.06 & 3 \\
\hline
\end{tabular}

not single-frequency data as in Jónsson et al. (1997). The 1993, 1994 and 1997 measurement campaigns were described in Jónsson et al. (1997). Also, the International GPS Service (IGS) benchmarks ZIMM, GRAZ, HERS, KOSG, MADR, MATE, ONSA, BRMU, WES2 and STJO data were used in order to compute the 1993 and 1994 campaigns.

In 2000, the effort was concentrated at the Furnas and Sete Cidades volcanoes and in 2002 Fogo volcano was also included in São Miguel network. The SMIG2000 campaign was carried out using Ashtech Z-12 and Leica (SR520 and CRS1000) receivers. Ashtech receivers were set with Ashtech Marine antennas (700700 series) and Ashtech Geodetic II (700228 series). Leica receivers were set with Leica Choke Ring AT504 and Leica Marine AT502. Each receiver was paired with its own antenna throughout the campaign, except for the Ashtech receivers, which were occasionally paired with a different model of Ashtech antenna. Five sites were measured during all the campaign (two in the east part of the island and two in the west part), including the International GPS Service (IGS) site PDEL. Benchmark MAR1 was not measured.

In SMIG2002 campaign, we used three different receiver/antenna associations: Ashtech Z-12 receiver with Geodetic II, Ashtech ZXTREM with Geodetic IV antennas, and Leica 520 with Leica Choke Ring 504. Again, each receiver was operated only with its own antenna. Otherwise, the points were measured with different pairs. Four sites were maintained as permanent all the time of data acquisition. MAR1 was measured in 2002 September jointly with permanent site PDEL.

\section{ANALYSIS AND RESULTS}

Three main groups of GPS sites were defined before the process: Azores, North America and Europe. In each group, the real-valued

\section{Sete Cidades Fogo Furnas}

\section{$30 \mathrm{~km}$}

Figure 3. The SãoMiguel GPS network in its 2002 campaigns. The twelve points symbolized by big filled diamonds have been observed at three epochs since 1993. PDEL location is indicated on the map. 
Table 2. Velocities in $\mathrm{mm} \mathrm{yr}^{-1}$ in the ITRF2000 (Altamimi et al. 2002) as displayed in Fig. 4. Mean Velocity E $12.6 \mathrm{~mm} \mathrm{yr}^{-1}, \mathrm{~N} 15.1 \mathrm{~mm} \mathrm{yr}^{-1}$. Sigmas denote one standard deviation. Residual velocities, after removing the mean appear in columns 4 and 5 .

\begin{tabular}{lcccccc}
\hline Site & Ve & Vn & V'e & V'n & $\sigma_{V e}$ & $\sigma_{V n}$ \\
\hline ALGA & 16.0 & 15.8 & 3.4 & 0.8 & 1.2 & 1.6 \\
BATA & 08.8 & 15.4 & -3.8 & 0.4 & 2.7 & 0.9 \\
GAF1 & 13.8 & 14.0 & 1.2 & -1.1 & 1.7 & 1.6 \\
GARC & 8.4 & 14.4 & -4.2 & -0.7 & 3.1 & 2.0 \\
GAS1 & 10.4 & 14.5 & -2.0 & -7.9 & 3.9 & 1.5 \\
FOGO & 14.5 & 15.0 & -1.5 & -6.2 & 2.8 & 3.7 \\
LAGO & 10.5 & 16.9 & -1.8 & 3.5 & 1.7 & 5.8 \\
MAIA & 14.0 & 15.1 & 1.4 & 0.8 & 1.9 & 0.8 \\
MAR1 & 14.8 & 16.2 & 2.3 & 1.1 & 1.1 & 1.2 \\
POCI & 14.7 & 14.3 & 2.1 & -0.8 & 6.8 & 4.7 \\
SALT & 12.4 & 15.5 & -0.2 & 0.4 & 1.2 & 1.1 \\
TIF3 & 12.7 & 13.8 & 0.1 & -1.3 & 1.6 & 1.7 \\
\hline
\end{tabular}

ambiguities were fixed. Indeed, we have chosen to search and solve the ambiguities for the baselines shorter than to $500 \mathrm{~km}$. Thus, the global solution provided by the processing software was not polluted by the mis-modelled long-baseline.

We have processed and analysed the data using the GAMIT/GLOBK processing suite (King \& Bock 2001; Herring 2005). For the SMIG2000 campaign, we estimate the position of 19 stations on São Miguel island and 28 IGS permanent benchmarks. We have computed the maximum WRMS scatters values and all of them all smaller than $50 \mathrm{~mm}$. All data sets were analysed with IGS data. We imposed no a-priori uncertainties on site coordinates. Each daily solution was adjusted using GLOBK (Herring 2005). The solutions computed here are in good agreement with the REVEL solution for the Nubia plate (see Fig. 2).

To estimate the absolute positions of the Azores stations in the ITRF2000 reference frame, we added data from the continuous IGS stations shown in Fig. 1. Using the longer time-series available for São Miguel Island, we were able to estimate the velocity vectors in ITRF2000 for several points mostly on the eastern part of the island (Table 2 and Fig. 5). Averaging these vectors we calculated the mean velocity of São Miguel Island to be $19.6 \pm 2.7 \mathrm{~mm} \mathrm{yr}^{-1}$ at N56.6 (Figs 4 and 5).

Next, we considered the internal deformation of São Miguel island using only the two most recent campaigns spanning the interval 2000.6 to 2002.7. By differencing the coordinates and dividing by the $2.1 \mathrm{yr}$ time interval, we can estimate the velocities of groups of stations with respect to the Nubia plate. We do this for the two groups of stations in the Furnas and Sete Cidades subnetworks as listed in Table 3. The mean displacement of the Sete Cidades and Furnas network with respect to the global motion of Eurasia are respectively of 3.3 and $2.5 \mathrm{~mm} \mathrm{yr}^{-1}$ with direction $\mathrm{N} 68^{\circ}$ and $\mathrm{N} 132^{\circ}$. We concluded that the east and the west parts of the island are moving apart. The orientation of the deformation is compatible with the focal mechanisms presented in the south of the island by Buforn (1988) and the observations made in the bathymetry describing strike-slip faulting cutting the oceanic crust with orientation $\mathrm{N} 120^{\circ}-\mathrm{N} 150^{\circ}$ Lourenço et al. (1998).

Accordingly, we interpret this internal deformation of São Miguel, not as the result of volcanic activity, but as transtension in a wide, boundary zone between the two plates. Such a boundary zone is compatible with diffuse deformation across the Terceira Rift. The shear zone between the Eurasia and Nubian plates is narrower in the east (São Miguel and Gloria Fault) than in the
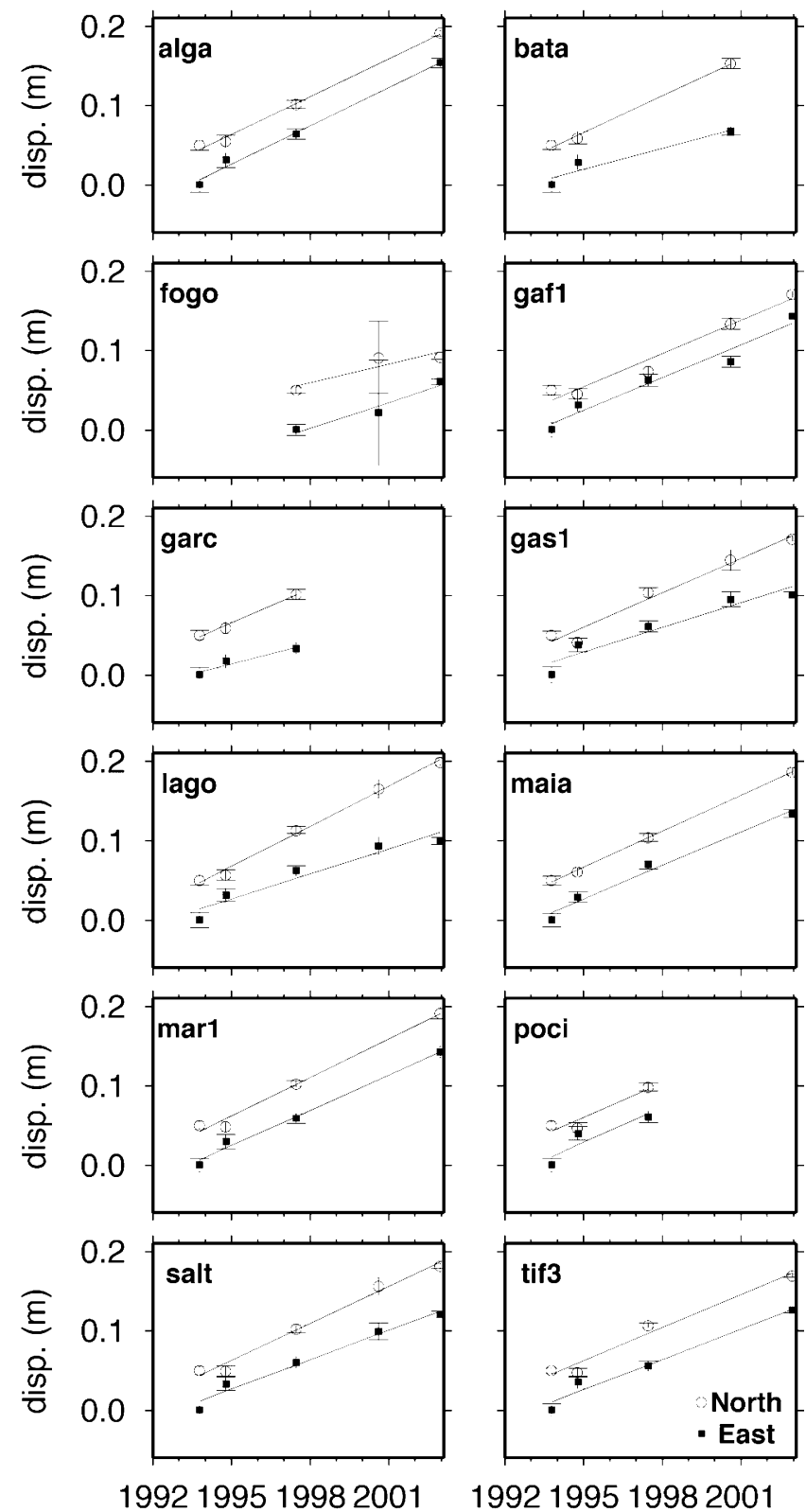

Figure 4. Time-series of positions estimated in the ITRF2000 reference frame of the twelve GPS points measured three or more times since 1993. The velocities are estimated by least-square adjustment of the coordinates changes, assuming a linear trend.

WNW toward the MAR. This motion implies a clockwise rotation and velocity gradient that could be measured with longer GPS time-series.

\section{DISCUSSION}

Several models have been proposed to explain the pattern and magnitude of local velocities and spreading directions of the Azores domain. Krause \& Watkins (1970) considered the evolution of the Azores triple junction as an evolution from a rift-fault-fault (RFF) to a ridge-ridge-ridge (RRR) junction. This evolution was responsible for the spreading direction change from E-W to NW-SE of the NU-NA boundary. McKenzie (1972) argued that the RFF to RRR evolution was due to oblique spreading along the EU-NU and 


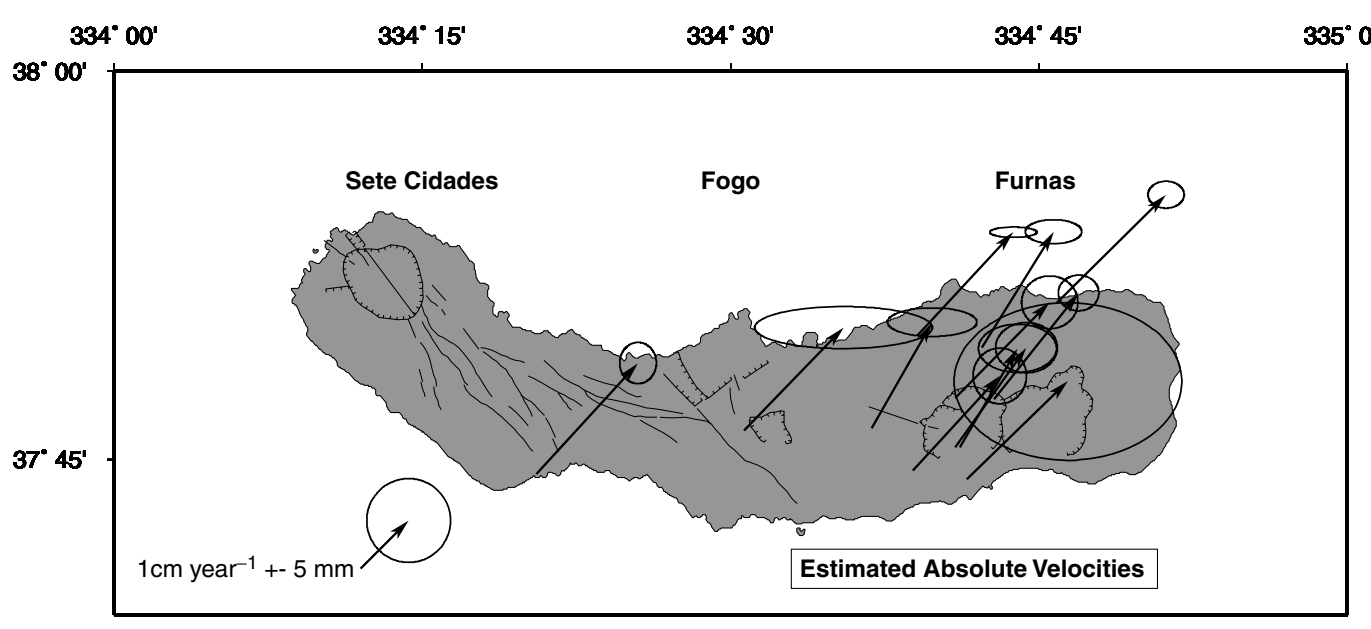

Figure 5. Absolute velocities deduced from the Furnas GPS time-series. All theses velocities are listed in Table 2.

Table 3. Sites of the GPS network located around Sete Cidades (Top) and Furnas (Bottom) volcanoes. Velocities in $\mathrm{mm} \mathrm{yr}^{-1}$ in East $\left(V_{e}\right)$ and North direction $\left(V_{n}\right)$ computed using SMIG2000 and SMIG2002 campaigns are given in this Table. FOG3 is located in Fogo volcano.

\begin{tabular}{lcrrrrr}
\hline Site & Lon. & Lat. & $V_{e}$ & $\sigma_{e}$ & $V_{n}$ & $\sigma_{n}$ \\
\hline PFR1 & 334.15 & 37.86 & 9.6 & 1.6 & 2.8 & 1.3 \\
GIN1 & 334.16 & 37.85 & -16.3 & 2.9 & -2.9 & 2.5 \\
ESC1 & 334.17 & 37.87 & -15.4 & 2.4 & 4.2 & 2.2 \\
MST2 & 334.18 & 37.90 & -29.5 & 1.8 & 3.2 & 2.3 \\
MLV1 & 334.19 & 37.87 & -3.9 & 2.2 & 11.7 & 2.9 \\
SET2 & 334.19 & 37.84 & -12.7 & 1.6 & 2.8 & 1.4 \\
SEA2 & 334.19 & 37.87 & 5.1 & 2.0 & 3.8 & 1.7 \\
MAF1 & 334.20 & 37.89 & -22.0 & 10.7 & -5.7 & 4.3 \\
SEA1 & 334.20 & 37.87 & 13.0 & 6.0 & -1.8 & 2.3 \\
FET1 & 334.20 & 37.81 & 13.5 & 1.9 & 6.3 & 1.9 \\
HMP1 & 334.21 & 37.84 & 7.4 & 0.9 & 0.3 & 0.5 \\
SET3 & 334.22 & 37.89 & -15.4 & 1.5 & 2.5 & 1.4 \\
GCV1 & 334.22 & 37.88 & -3.3 & 5.6 & -4.3 & 3.2 \\
TMG1 & 334.22 & 37.82 & 10.2 & 1.8 & 1.5 & 1.3 \\
PCR2 & 334.24 & 37.85 & -2.4 & 1.5 & 2.5 & 1.5 \\
PVR1 & 334.25 & 37.89 & -11.5 & 4.6 & -5.4 & 3.5 \\
MCR1 & 334.26 & 37.83 & 6.0 & 1.8 & -0.6 & 1.5 \\
MRH1 & 334.26 & 37.87 & -14.5 & 2.4 & 1.8 & 2.5 \\
MCA1 & 334.30 & 37.84 & -6.9 & 1.4 & 3.3 & 1.2 \\
CCVA & 334.32 & 37.81 & 3.0 & 1.2 & -1.4 & 1.1 \\
PDEL & 334.34 & 37.75 & 6.8 & 0.9 & -1.5 & 0.5 \\
BRG1 & 334.48 & 37.82 & 12.3 & 1.2 & 4.4 & 1.1 \\
& & & & & & \\
FOG3 & 334.51 & 37.77 & 12.2 & 20.9 & 2.7 & 13.5 \\
& & & & & & \\
BVF1 & 334.55 & 37.72 & 4.2 & 0.9 & -1.6 & 0.6 \\
CED1 & 334.64 & 37.76 & -1.4 & 2.2 & -3.2 & 2.3 \\
VIF1 & 334.65 & 37.74 & 8.9 & 1.3 & -1.1 & 1.2 \\
LOM1 & 334.65 & 37.83 & 9.5 & 0.9 & 1.0 & 0.7 \\
GAF1 & 334.68 & 37.79 & 10.7 & 1.6 & 0.7 & 1.5 \\
GAF2 & 334.69 & 37.80 & 10.2 & 11.0 & 2.8 & 2.9 \\
CPC1 & 334.70 & 37.77 & 8.0 & 2.0 & 0.6 & 2.0 \\
LAG1 & 334.70 & 37.82 & -11.3 & 2.4 & -13.0 & 2.3 \\
SALA & 334.71 & 37.79 & -12.4 & 2.2 & -5.3 & 2.1 \\
QBP1 & 334.77 & 37.75 & -12.0 & 1.6 & 1.1 & 1.9 \\
QBN1 & 334.85 & 37.84 & 6.1 & 0.9 & -0.2 & 0.4 \\
\hline & & & & & &
\end{tabular}

NU-NA plate boundaries near the Azores, and northward migration of the triple junction. Searle (1980), based on geophysical and bathymetric data, showed that the change was in fact due to evolution of transform faults. He identified a 130-160-km-wide zone ranging
Table 4. Plate velocities displayed in Fig. 6 in $\mathrm{mm} \mathrm{yr}^{-1}$. REVEL solutions from (Sella et al. 2002). Formal uncertainties (sigmas) represent one standard deviation.

\begin{tabular}{lcccc}
\hline Site & $\mathrm{Ve}$ & $\mathrm{Vn}$ & $\sigma_{V e}$ & $\sigma_{V n}$ \\
\hline REVEL Eurasia & 16.94 & 14.9 & 0.5 & 0.6 \\
REVEL Nubia & 11.3 & 14.2 & 0.9 & 0.8 \\
Our solution at PDEL & 12.30 & 14.10 & 2.6 & 2.3 \\
\hline
\end{tabular}

from the Formigas to the Graciosa islands, which he named the Azores spreading centre that appears to have developed as a series of an echelon rifted basins (Terceira rift). The Terceira rift, trending ESE-WNW, appears to accommodate most of the deformation in the boundary zone between the Eurasia and Nubia plates. The detailed kinematics along the zone, the stress field regime and magma feeding system remain, however, questions of extensive research. Our longer GPS time-series (Fig. 4) for stations located mainly on the eastern part of São Miguel Island, yields that a mean velocity vector for the 1993-2002 period fits approximately the velocity of Nubia plate as given by the REVEL model (Table 4). Neglecting a systematic error in the REVEL solution, we infer that the eastern part of Sao Miguel moves with the Nubia plate. Alternatively, the REVEL model may not fully describe the motion, as the São Miguel island is within the plate boundary deformation zone. Future GPS data acquisition will certainly give insights for hypothesis discrimination and allow improvement of local deformation models.

Based on the mean displacement vectors obtained from eastern and western parts of the São Miguel Island, we conclude that these two areas are moving apart (Fig. 6). However, we can identify significant heterogeneities in the velocity field in each of the two areas. Varying orientation and magnitudes of displacement vectors in each of the areas may be due to uncertainty (short GPS time-series), volcanic edifice deformation, or a combination of both. Indeed, most of the GPS monuments lie on the active stratovolcanoes of Sete Cidades and Furnas active stratovolcanoes. The eastern and western blocks of São Miguel should not be expected to act as perfectly rigid blocks. The observed extension between the two areas can be compared to the relative movement between the $\mathrm{Nu}-$ bia and the Eurasia plates. The Nubia and Eurasia Plates relative velocity expected by following the REVEL solutions is equal to $5.68 \mathrm{~mm} \mathrm{yr}^{-1}$ on at $\mathrm{N} 82^{\circ}$ (assuming the EU-NU boundary lies in between the areas) and differs somewhat our solution and 


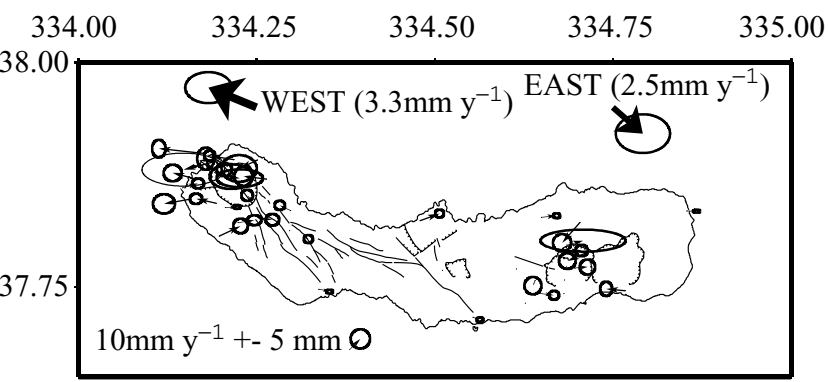

Figure 6. Velocities estimated for the 2000-2002 period, from the SMIG2000 and 2002 campaigns, after removing the mean vector of the benchmarks measured during these two campaigns.

introduces an extension between the eastern and the western blocks of the island of $5.73 \mathrm{~mm} \mathrm{yr}^{-1}$ at N120.7 . These two velocity vectors agree in magnitude, but not orientation. The cause of this difference is not yet clear. However, we can state that a narrow zone some $15-25 \mathrm{~km}$ wide appears to accommodate most of the deformation in between the Nubia and Eurasia plates. Future GPS surveys will allow further definition of the main deformation area, as well as allowing extraction of volcanic deformation from global plate motion. Jónsson et al. (1997) used GPS data gathered mainly in the Furnas region, eastern Azores, to hypothesize that a 10$15 \mathrm{~km}$ wide zone across São Miguel accommodates about 75 per cent of the plate divergence between NU-EU plates (about $3 \pm 1 \mathrm{~mm}$ at N78 ${ }^{\circ}$ according to DeMets et al. 1994). Our study suggests a zone of similar width accommodating the motion, but places the extension more on the central area of São Miguel (in between Fogo and Sete Cidades volcanoes). Furthermore, our study indicates that global plate motion models such as REVEL seem to explain only part of the observed deformation, suggesting additional local deformation eventually of volcanic origin on São Miguel Island. The extensional regime in the central part of São Miguel may weaken the crust and favour magma intrusion and volcanic unrest in this area. Improvement of geodetic networks and increasing GPS data acquisition will give crucial information for modelling, volcano monitoring, and understanding of the complex tectonics taking place at the boundary between the Nubia and Eurasia plates in the Azores region.

\section{ACKNOWLEDGMENTS}

We gratefully thank Mr Peter Molnar for the comments he made on our work.

\section{REFERENCES}

Abdel-Monem, A.A., Fernandez, L.A. \& Boone, G.M., 1975. K-Ar ages from the eastern Azores group (Santa Maria, São Miguel and the Formigas Islands), Lithos.
Altamimi, Z., Sillard, P. \& Boucher, C., 2002. ITRF2000: a New Release of the International Terrestrial Reference Frame for Earth Science Applications, J. geophys. Res., 107(B10), ETG 2-1 to ETG 2-19.

Bastos, L., Osório, J., Barbeito, A. \& Hein, G., 1998. Results from geodetic measurement in the western part of the African-Eurasian plate boundary, Tectonophysics, 294, 261-269.

Buforn, E., 1988. Udías and Colombás, Seismicity, source mechanisms and tectonics of the Azores-Gibraltar plate boundary, Tectonophysics, 152, $89-118$

Cannat, M.A. et al., 1999. Mid-Atlantic ridge-azores hotspot interactions: along-axis migration of a hotspot-derived event of enhanced magmatism 10 to 4 Ma ago, Earth planet. Sci. Lett., 173, 257-269.

DeMets, C., Gordon, R.G., Argus, D.F. \& Stein, S., 1994. Effect of recent revisions to the geomagnetic reversal time scale on estimates of current plate motions, Geophys. Res. Lett., 21(20), 2191-2194.

Herring, T., 2005. GLOBK: Global Kalman Filter VLBI and GPS Analysis Program, version 10.2, Massachusetts Institute of Technology, Cambridge, Massachusetts.

Jónsson, S., Alves, M.M. \& Sigmundsson, F., 1999. Low rates of deformation of the Furnas and Fogo volcanoes, São Miguel, Azores, observed with the Global Positioning System, J. Volc. Geoterm. Res., 92, 83-94.

King, R.W. \& Bock, Y., 2001. Documentation for the GAMIT Analysis Software Version 10.0, Massachusetts Institute of Technology, Cambridge, Massachusetts.

Krause, D.C. \& Watkins, N.D., 1970. North Atlantic crustal genesis in the vicinity of the Azores, Geophys. J. R. astron. Soc., 22, issue 1-2, 151152.

Lourenço, N., Miranda, J.M., Luis, J.F., Ribeiro, A., Mendes Victor, L.A., Madeira, J. \& Needham, H.D., 1998. Morpho-tectonic analysis of the Azores Volcanic Plateau from a new bathymetric compilation of the area, Mar. Geophys. Res., 20, 141-156.

Machado, F., 1959. Submarine pits of the Azores Plateau, Bull. Volc., Serie II, Tome XXI, pp. 109-116.

Madeira, J. \& Ribeiro, A., 1990. Geodynamic models for the Azores triple junction: a contribution from tectonics, Tectonophysics, 184, 405-415.

McKenzie, D.P., 1972. Active tectonics of the Mediterranean region, Geophys. J. R. astron. Soc., 30, 109-185.

Namias, J., 1974. Suggestions for research leading to long range precipitation forecasting for the tropics, paper presented at International Tropical Meteorology Meeting, Am. Meteorol. Soc., Nairobi, January 31 to February 7.

Queiroz, G., 1998. Vulcão das Sete Citades (S. Miguel, Acores) historia eruptiva e avaliacão do hazard. PhD thesis, University of the Azores.

Searle, R., 1980. Tectonic pattern of the Azores spreading centre and triple junction, Earth. planet. Sci. Lett., 51, 415-434.

Sella, G.F., Dixon, T.H. \& Mao, A., 2002. REVEL: A model for Recent plate velocities from space geodesy, J. geophys. Res., 107(B4), ETG 11-1 to ETG 11-12.

Sigmundsson, F., Tryggvason, E., Alves, M.M., Alves, J.L., Pálsson, K. \& Ólaffson, H., 1995. Slow inflation of the Furnas volcano, São Miguel, Azores, suggested from initial leveling and Global Positioning System measurements, Geophys. Res. Lett., 22(13), 1681-1684.

Weston, F., 1964. List of the recorded volcanic eruptions in the Azores with brief reports, Bol. Mus. Lab. Min. Geol. Fac. Cincias de Lisboa, 10, 3-18. 